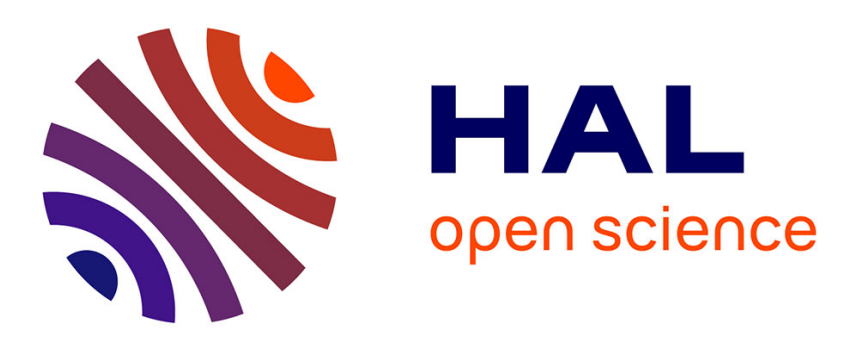

\title{
Transportation Conditions and Access to Services in a Context of Urban Sprawl and Deregulation. The Case of Dar es Salaam
}

\author{
Lourdes Diaz Olvera, Didier Plat, Pascal Pochet
}

\section{- To cite this version: \\ Lourdes Diaz Olvera, Didier Plat, Pascal Pochet. Transportation Conditions and Access to Services in a Context of Urban Sprawl and Deregulation. The Case of Dar es Salaam. Transport Policy, 2003, 10 (4), pp. 287-298. 10.1016/S0967-070X(03)00056-8 . halshs-00068249}

\section{HAL Id: halshs-00068249 \\ https://shs.hal.science/halshs-00068249}

Submitted on 15 Sep 2006

HAL is a multi-disciplinary open access archive for the deposit and dissemination of scientific research documents, whether they are published or not. The documents may come from teaching and research institutions in France or abroad, or from public or private research centers.
L'archive ouverte pluridisciplinaire $\mathbf{H A L}$, est destinée au dépôt et à la diffusion de documents scientifiques de niveau recherche, publiés ou non, émanant des établissements d'enseignement et de recherche français ou étrangers, des laboratoires publics ou privés. 


\title{
TRANSPORTATION CONDITIONS AND ACCESS TO SERVICES \\ IN A CONTEXT OF URBAN SPRAWL AND DEREGULATION \\ THE CASE OF DAR ES SALAAM
}

\author{
Lourdes Diaz Olvera, Didier Plat, Pascal Pochet* \\ Laboratoire d'Economie des Transports \\ Ecole Nationale des Travaux Publics de l'Etat \\ Rue Maurice Audin \\ 69518 Vaulx-en-Velin cedex \\ France
}

* corresponding author. e-mail: pochet@entpe.fr 



\title{
TRANSPORTATION CONDITIONS AND ACCESS TO SERVICES IN A CONTEXT OF URBAN SPRAWL AND DEREGULATION THE CASE OF DAR ES SALAAM
}

DIAZ OLVERA Lourdes, PLAT Didier, POCHET Pascal (2003), Transportation conditions and access to services in a context of urban sprawl and deregulation. The case of Dar es Salaam, Transport Policy, Vol. 10, n 4, pp. 287-298.

\begin{abstract}
The population of Dar es Salaam travels very little and under difficult conditions. The available information indicates a low level of daily mobility severely limited by local conditions, thus revealing a great discrepancy between transportation needs and the means to satisfy them. Over the past few years, a number of general factors have contributed to worsening this discrepancy, including explosive population growth, increasing poverty, rapid and disorderly expansion of the urbanised zone, reinforcement of the split between residential, employment and service areas, and the deregulation process. The deficiencies in the transport system, in terms of both infrastructure and service provision, further complicate daily life by hindering access to urban facilities for a majority of households, notably the poor. Analysis of the 1993 HRD Survey shows that the city runs the risk of splitting in two. On the one hand, the priviledged population groups have access to quality infrastructure and services. On the other hand, the vast majority, with low income, is confronted with poor urban facilities and excessively expensive public transportation with respect to their budget. Consequently, the poor tend to retreat into their neighbourhood, but this situation does not contribute to developing broader human and social capital and economic opportunities. Instead, it probably constitutes a poverty trap. To ensure a minimum degree of equity throughout the city as a whole, the public authorities must reassume a role in improving access throughout the city as well as the availability of basic local services, two interdependent aspects of public policy to alleviate poverty.
\end{abstract}

\section{Introduction}

The gap between transportation needs and the means to satisfy them are very great in Dar es Salaam today. The main city of one of the poorest countries in Africa is confronted with tremendous population growth accompanied by rapid and unplanned urban sprawl with a split between residential zones on the one hand and zones for employment, trade, health services, etc. on the other. In a general context of poverty affecting the inhabitants as well as local and national finances, the failure of the period of "bottom-up socialism" paved the way to a form of "development from below" (Eriksen, 1997). Private players and companies, non-governmental organisations, consumers and associations are 
encouraged to replace the failing public authorities (Therkildsen, Semboja, 1995, Munishi, 1995). Similar to a number of other situations (Werlin, 1999, Vasconcellos, 2001), this political orientation imposed by the lending institutions has for the time being produced dubious results in Dar es Salaam (Plat, Pochet, 2002).

In terms of transportation, the extremely rapid deregulation has resulted in the development of private companies, the daladalas, generally in the form of small entrepreneurs but occasionally speculative as well, running different sizes of minibuses and buses, which now provide virtually all urban passenger transport. The vitality and the great number of informal transport operators have compensated the lack of public transport caused by the gradual decline of the urban public transport company UDA. However, the current transport system has great difficulty in covering the increase in both urban population and surface area and in meeting the basic needs of its inhabitants, particularly the poorest. In the absence of a regulation agency, the daladalas tend to focus on the most profitable lines as well as on the most profitable clienteles. For example, in 1998, 53 of the 83 informal transport lines were radial and served the Central Business District (CBD) (Berhie, 1998).

The first part of this paper will draw up an overview of the urban sprawl affecting Dar es Salaam and the trends in public transport toward a system dominated by the small entrepreneurs. To assess the access conditions to urban facilities and daily mobility depending on the residential area, the second and third parts will present the results of an analysis on the Dar es Salaam sample in the HRDS (Human Resources Development Survey). Finally, the last part will conclude by mentioning the negative consequences of difficult access to facilities on efforts to alleviate poverty.

\section{Urban growth, deregulation and transport provision}

According to census data, the population of Dar es Salaam was 348000 in 1968, 852000 in 1978 (i.e. an annual growth rate of 9.4\%) and 1345000 in 1988 (i.e. an annual growth rate of $4.7 \%$ since 1978). The current number of inhabitants may be estimated at 2.5 to 3 million. This urban growth is comparable to that noted in other African countries where the rate is of 5.2\% between 1975 and 1998 (Razafindrakato, Roubaud, 2001). Population growth has probably not slowed over the last few years and this high rate, virtually uncontrolled by the local authorities, has resulted in a division, both functional and spatial, of the city, with spectacular growth of urban zones in a fan-like pattern (Banyikwa, 1988), initially along the major roads, then by filling in the zones in between, through the development of unplanned neighbourhoods.

The surface area of the city was thus multiplied by a factor of five from 1968 to 1982 (Maunder, Fouracre, 1987). The maximum distance from centre to fringe, only 6 to 10 kilometres in 1969 , rose to $15 \mathrm{~km}$ in 1978 and then to $30 \mathrm{~km}$ along certain roads in the middle of the 1990s (Kombe, 1994). At the turn of the century, the urban area spread in a discontinous manner $35 \mathrm{~km}$ from north to south and $30 \mathrm{~km}$ from east to west. Urban growth, which continued at a rapid pace through the 1990s, changed however, with infill and higher densities in the interstitial areas replacing to a large extent the linear expansion noted previously (Briggs, Mwafumpe, 2000). The great majority of the population lives within 
$10 \mathrm{~km}$ of the centre, but that nonetheless constitutes a considerable distance given the radial structure of the existing road network (see Figure 1).

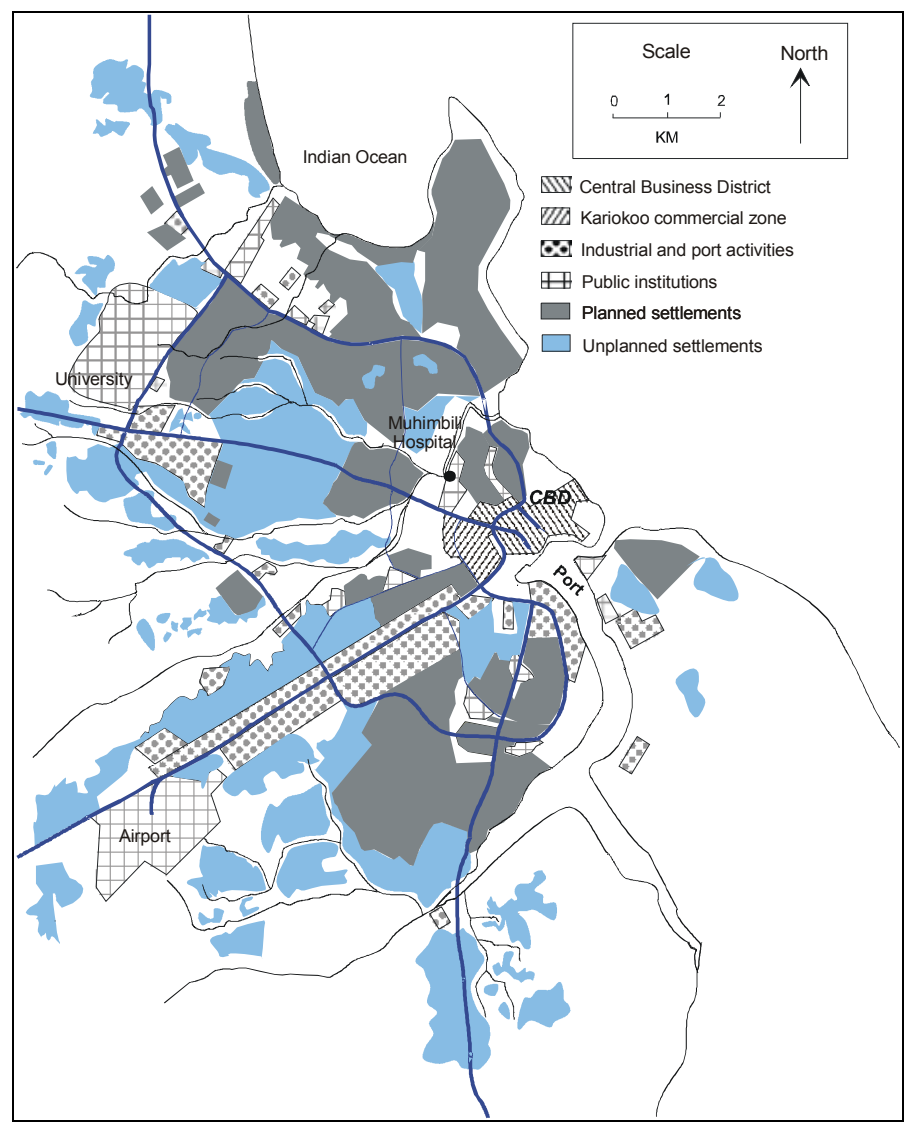

Figure 1. Residential and employment zones and main facilities.

This spatial dispersion of the areas of residence causes all the more problems that jobs and the main urban facilities are highly concentrated in the CBD or nearby. The main commercial district (Kariakoo), the largest market, the main hospital (Muhimbili), the industrial zone and the port are all close to the centre (see Figure 2). Even though the concentration of economic and employment zones in a limited area is, of course, not total (for example, the university is located on the fringe), Dar es Salaam is characterised by a high level of spatial specialisation and the separation of residential and employment zones which leads to increasing transportation needs between distant zones.

\subsection{Dual road network}

The network of main arterial roads has received considerable work (resurfaced and widened) since the beginning of the 1990s. The main purpose of this work, carried out with foreign financing, was to maintain exchanges between the business sectors and the peripheral residential areas. The usually good condition of the main roads contrasts with the poor conditions, increasingly visible over the past ten years, of the local access roads within the peripheral residential areas.

Moreover, travel is just as difficult within the neighbourhoods as well. Local roads, rarely paved, make for uncertain travel by four-wheel vehicles and the minibuses must weave between ruts at a very low speed. Travel conditions can 
even become impossible during the rainy season, when the increasing number and depth of holes can completely block vehicles. The very few car drivers leave their vehicle at the entry of the neighbourhood, taxis demand double fare or simply refuse to enter, goods must be transported using carts, etc. Non-motorised travel is also difficult and occasionally dangerous due to the absence of sidewalks and reserved lanes, as well as the clogging of streets by shops and even unauthorised dumps. Daily trips on foot are also made much more complex by the rains and people can be cut off in their neighbourhood by the collapse of road or rail bridges, as in Tabata in 1998. They are then obliged to cross flooded rivers, sometimes at great risk, or at times simply do not know where to go through the flooded streets.

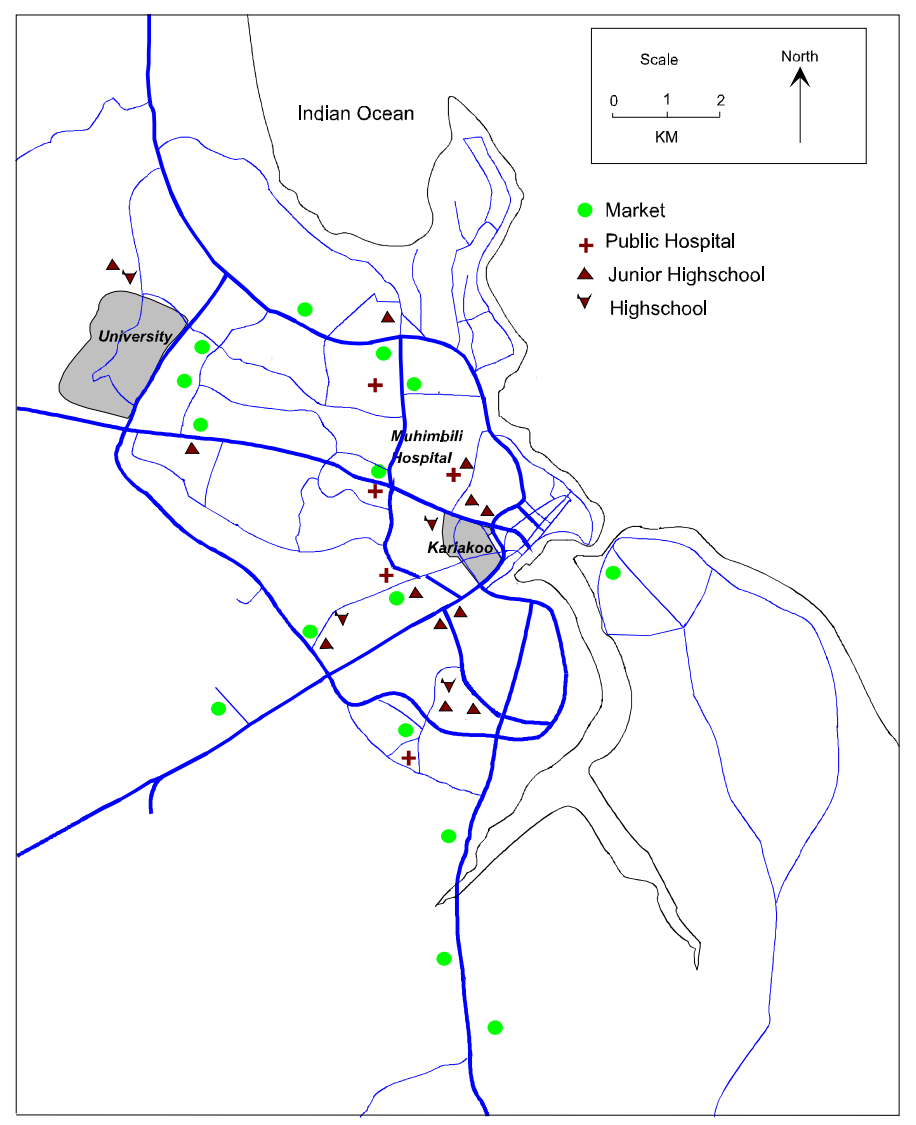

Figure 2. Location of various urban facilities.

These access problems, noted even in the richest residential areas (occasionally called "modern slums" for this reason), weigh more heavily on the daily life of the inhabitants of the squatter settlements. They reveal a larger planning problem in areas that are frequently the product of individual, uncoordinated initiatives. Most often, access roads were not planned from the start and their construction after the arrival of the population raises problems, both technical (unsuitable terrain) and social (widening of roads often requires destruction of homes and commercial premises).

This double nature of the road network, i.e. fairly well maintained radial main roads and poor collector roads, has over the past few years caused severe problems concerning the interconnection between residential areas and increasing differences in the quality of access to the centre, which depends of course on the 
distance to the centre and, even more important, on the distance to paved roads and public transportation.

\subsection{Rapid change on the public transportation market}

Starting early in the 1980s, UDA, the public company nationalised in 1970 following the Arusha declaration, encountered major operating difficulties. Given the deficient technical conditions of the bus fleet, at best half of the buses could be operated each day, the number of kilometres driven each year steadily dropped and the number of passengers consequently also decreased. With little or no support, notably financial, from the overseeing entities, UDA suffered considerable erosion in its market share throughout the decade, particularly given steady increase in competition from the private sector.

Already in the 1970s, inexpensive Korean pick-ups were specially imported and outfitted locally at very low cost to transport passengers. Their tariffs progressively increased until they reached TSH 5 in 1981, thus earning the name daladala, the word in Swahili for the TSH 5 coin. In 1983, they were authorised on fixed routes and their number then increased rapidly, reaching 300 in 1985. In practice, there were no operating constraints and the activity was so profitable that certain employees invested in the private transport sector and thus managed to limit the drop in their standard of living during the economic crisis that hit the country (Martin, 1988). Precise figures are not available, however, the capacity of the private sector (daladalas, as well as taxis and company transportation of employees) during the middle of the 1980s was roughly equivalent to that of UDA. In just a few years, the situation for the public company shifted from a legal (if not real) monopoly to one of strong competition.

The configuration of the transport supply has since changed rapidly. At the end of the $1980 \mathrm{~s}$, UDA again faltered and fell to a market share of barely $10 \%$, whereas the illegal daladalas became the number one supplier of passenger transport (Transurb Consult, Inrets, 1991). Many taxis were also active, perhaps 3 000. In 1991, the daladalas were probably about 1000 in number, of which one half were illegal. The UDA network, on the other hand, which remained structured around fixed itineraries, fell to only 25 lines. In 1995, this number again fell to 12 (for 72 vehicles), whereas 1500 taxis were officially registered and 2000 daladalas, on average, daily flowed through the city along 87 lines. Over the second half of the decade, the number of private small-scale entrepreneurs continued to rise. The press mentioned figures as high as 7000 daladalas and almost 4500 taxis (of which two-thirds were illegal), whereas the UDA fleet fell to almost ridiculous levels, with less than 40 buses in 1998 and only 12 in 2000 (Howe, Bryceson, 2000). The urban passenger transport sector, virtually deregulated de facto, is now based on small entrepreneurs. The services offered by the daladalas are now characterised by a very radial configuration, essentially concentrated on the $150 \mathrm{~km}$ of main roads, as was shown by the trafficcount data collected by Sawaka (1996).

As in most Subsaharan African cities, the end of the century was characterised by an uncontrolled proliferation of private operators and by the disappearance (de facto in Dar es Salaam, through legal measures elsewhere) of the state transport company whose creation was often the symbol of the newly acquired independence. Deregulation took place gradually and was driven more by a lack of interest and funding in the sector than by ideological criteria. The 
successive and/or simultaneous regulatory entities for UDA (the NTC, a state company in charge of intercity transport in the whole country, or the city government, through various institutions) rapidly gave up on the idea of attempting to manage the company and, for example, let it renew its fleet haphazardly, without any long-term policy, thus playing into the hands of the private competition. However, this proliferation of private operators has resulted in an insufficient level of quality and many urban dwellers are confronted with unsatisfactory conditions in terms of daily mobility.

\section{Varying access conditions to urban facilities in the city}

The Human Resources Development Survey (HRDS), carried out in 1993, provides the raw data required to assess the structural difficulties of Dar es Salaam residents and in particular to reveal the unequal conditions between inhabited areas by distinguishing three types of residential zones, i.e. affluent, planned and unplanned wards (see Box 1).

Box 1. Characteristics of the HRD Survey and the Dar es Salaam sub-sample.

The HRD Survey was carried out by the Department of Economics of the University of Dar es Salaam, the Government of Tanzania and the World Bank (Ferreira, Griffin, 1996), and was funded by the World Bank, the Government of Japan and the British Overseas Development Agency. It covered 5000 households on the national level and included a sub-sample of 1128 households representing the population of Dar es Salaam, which constitutes the source of the statistical data presented in this article. The survey evaluated access conditions to various necessities, i.e. health and education facilities, water and electricity, food markets, road infrastructure for the households located in various urban areas. Other collected data concerned housing conditions, socio-demographic characteristics and the annual expenditure of the households.

Depending on the housing characteristics of the studied households, we distinguished three different types of wards, i.e. unplanned wards (representing $47 \%$ of the households), predominantly planned wards (31\%) and affluent wards $(22 \%)$. A majority of houses in the unplanned wards do not have running water or electricity, whereas Western-style houses are numerous in the affluent wards and a great majority have running water and electricity. Finally, the non-affluent planned wards (hereinafter called simply the planned wards) represent a median position between the two extremes.

There is no clear separation in housing conditions between the three types of wards (e.g. squatter settlements may be found in the middle of planned wards) and there is also no clear distinction in social conditions between the planned and unplanned wards. The unplanned wards comprise a majority of households with unemployed members and whose active members work in the "informal" or private sector, whereas the planned wards have a majority of civil servants with regular revenues making it possible to obtain higher housing standards. The unplanned wards are home to the poorest inhabitants with an annual expenditure per household of approximately TSH 800000 on average, as compared to TSH 1.06 million in the planned wards and TSH 1.55 million in the affluent wards (TSH $1000=$ USD 2.7 in 1993). 


\subsection{Access to water and food markets}

The daily constraints experienced by the poorest households due to the lack of infrastructure or more difficult access to basic services are made even more clear when the question of the water supply is analysed (see Table 1). Limited access to water is a problem for many households because, whatever the type of ward, almost one third of all people declare that, during a normal day, they must travel to obtain water (38\% in the unplanned wards, $32 \%$ in the planned wards and $23 \%$ in the richer wards). In almost three households out of four, this task is carried out by the women. Living in a home without running water, by far the most common situation in the unplanned areas, results in major inconveniences in daily life which are worsened by the relative scarcity of fountains and other water sources. In the unplanned wards, for over one woman (or young girl) out of two and one man out of five, collecting water takes on average almost one hour per day. Not only is the percentage of the concerned people in these wards much higher, the difficulty is also greater and water consumption is limited to the essential needs. When the distance to a source or the difficulty is too great, people may use the services of itinerant water vendors. This is the case for almost one household out of five in the unplanned wards, but this solution obviously increases the cost of access to this essential resource.

Table 1. Water supply depending on the type of ward

\begin{tabular}{|c|c|c|c|c|}
\hline & Unplanned & Planned & Affluent & All \\
\hline Homes with running water $(\%)$ & 12 & 36 & 76 & 34 \\
\hline Purchase from itinerant vendors $(\%)$ & 18 & 12 & 3 & 13 \\
\hline $\begin{array}{l}\text { Mean distance to water, for homes } \\
\text { without (in metres) }\end{array}$ & 280 & 120 & 20 & 190 \\
\hline $\begin{array}{l}\text { Mean time to obtain water per home, for } \\
\text { homes without (in minutes) }\end{array}$ & 59 & 34 & 20 & 55 \\
\hline
\end{tabular}

Table 2. Location of food purchase depending on the type of ward.

\begin{tabular}{lllll}
\hline Place of purchase (\%) & Unplanned & Planned & Affluent & All \\
\hline Market & 65 & 68 & 77 & 69 \\
Store in the ward & 33 & 30 & 23 & 30 \\
Store outside the ward & 1 & 1 & 0 & 1 \\
Purchase from neighbours & 1 & 0 & 0 & 0 \\
\hline Mean distance to place & 450 & 630 & 660 & 550 \\
Mean time (1-way, in minutes) & 8 & 11 & 10 & 9,5 \\
Percentage of travel on foot & 100 & 95 & 89 & 95 \\
\hline \multicolumn{1}{c}{ Source: HRDS in 1993} & & & &
\end{tabular}

Source: HRDS in 1993

Similar constraints exist for households in purchasing food. The distance to markets offering the greatest variety of products poses a comparable problem, i.e. either accept the long travel (time, cost, inconvenience), or go to the small local stores and accept a much higher price, as already noted by De Langen (1994). The HRDS confirms that for food purchases, small stores are slightly closer for residents in the unplanned wards (see Table 2). The fact that people go to small 
local stores is probably not because they choose to do so, but is rather due to the lack of nearby markets because almost all the large sites to purchase food are near the main roads. Concerning markets, similar to the other services, they tend to be more numerous in the older neighbourhoods.

\subsection{Access to education and health services}

The affluent wards are the best equipped in school and health facilities, the contrary being true for the unplanned wards. Only the primary schools (see Table 3 ) and the community dispensaries (see Table 4), basic local services, are as numerous in the unplanned wards as in the rest of the city. These results are confirmed by the shorter distance covered by school children in the unplanned wards. For children from poorer families, this shorter distance is certainly due to both the end of schooling at a younger age and the difficulty of attending private schools, more costly than the public schools. As a result, in the unplanned zones, children are more likely to go to the public primary schools, closer to the home, than children in the planned ones. Furthermore, over the past few years, the gap between rich and poor has increased due to the significant drop in attendance in primary schools for children from poor families (Lugalla, 1997). To encourage education, the authorities have requested that the daladalas transport them at a reduced fare. However, given the absence of any financial compensation, the daladalas tend to refuse the rather unprofitable clientele of school children at rush hour, as demonstrated by the increase in the number of incidents and discrimination concerning school children reported by the press.

Table 3. Mean distance from home to schools depending on the type of ward, in kilometres.

\begin{tabular}{lllll}
\hline & Unplanned & Planned & Affluent & All \\
\hline Public primary school & 1,1 & 0,8 & 0,8 & 0,9 \\
Private primary school & 6,7 & 5,6 & 3,8 & 5,1 \\
Public secondary school & 5,7 & 4,5 & 3,4 & 4,8 \\
Private secondary school & 3,7 & 3,0 & 3,1 & 3,9 \\
Trip distance for school children & 1,7 & 1,8 & 2,4 & 2,0 \\
\hline
\end{tabular}

Source: HRDS in 1993

Table 4. Distance from home to health services depending on the type of ward, in kilometres.

\begin{tabular}{lllll}
\hline & Unplanned & Planned & Affluent & All \\
\hline Public dispensary & 2,3 & 2,6 & 1,7 & 2,3 \\
Private dispensary & 1,0 & 1,3 & 0,9 & 1,1 \\
Public hospital & 4,7 & 3,2 & 2,9 & 3,9 \\
Private hospital & 6,3 & 4,9 & 4,4 & 5,4 \\
\hline
\end{tabular}

Source: HRDS in 1993

Some $75 \%$ of all trips to health facilities is on foot, $20 \%$ in public transport and barely $5 \%$ uses an individual form of transport (car, taxi or bicycle). Consequently, the distance to a dispensary is a particularly limiting factor, which explains why long walks are rare and less than one in four exceeds one kilometre (Amer, 1998). 
A study on three health centres at different levels in the hierarchy (Mwananyamala hospital, Sinza clinic and Tandale dispensary) confirms the decisive role of travel on foot (Zambrano Gil, 1994), with 95\% for the local Tandale dispensary, $78 \%$ for the hospital and $62 \%$ for the clinic, the latter being the only one served by good public transport. It would therefore appear logical that, given the absence or difficulty in obtaining motorised travel, the distance is the primary criterion in selecting a public health centre, as shown by the answers to the surveys. On the other hand, over $50 \%$ of the people going to private establishments used motorised transportation, primarily the daladalas, as compared to $12 \%$ on average for the public establishments covered in the study. The use of transportation other than on foot signifies a much wider choice of medical establishments and is beyond the means of poor families. In addition to the costs, already dissuasive, of health care, the cost and inconvenience of travel to and from the establishment also reduce the use of health services and are an indirect but real obstacle to improving the health of the poor inhabitants. The lack of facilities in wards is worsened by the unequal access to transportation networks.

\subsection{Access to roads}

The closest road is, on average, 300 metres from the home and provides passenger transportation in only two cases out of three. This distance to the closest road varies by a factor of up to two between affluent and unplanned wards and this factor can increase to 2.5 for roads offering public transport. Though the average distance may not seem very great, situations are very different within each type of ward. Some homes are very close to a road, others are over a kilometre distant. Given the large distances between stops on the daladalas lines, the closest stop is often 1 to $2 \mathrm{~km}$ from the home, which means 15 to 30 -minute walks and a considerable increase in both daily travel times and inconvenience, particularly in light of the fact that these figures are only one-way.

The quality of roads also varies. In unplanned wards, access roads sized for four-wheel motor vehicles are paved for only $46 \%$ of homes, as compared to $55 \%$ in planned wards and $60 \%$ in affluent wards. Access to public transport is satisfactory in planned wards ( $77 \%$ of homes) and is paradoxically similar in the unplanned (62\%) and the affluent wards (64\%). The situation in the latter group, where some of the people have personal cars, may be explained by less demand for public transport than elsewhere. Consequently, the situation for the least rich people in these areas and for those who work there is just as poor as in the unplanned wards.

Access problems to urban facilities are therefore cumulative. Lack of accessibility and services in wards go hand in hand. The consequences are double. First, daily travel is longer and more difficult, secondly, costs are higher for the essential acts of daily life, such as the use of two daladalas to go to work and the purchase of small quantities of food. Therefore, the cost of travel is extremely dissuasive for households who often have very low revenues. 


\section{Decreasing solvent demand for transportation}

The unfavourable conditions for motorised daily travel result in high costs for households and use of public transportation reduced to the absolutely essential activities.

\subsection{Major strain on the household budget}

The expenditure devoted by households to the daily trips of their members may be assessed on the basis of a number of different studies. According to the HRDS (see Table 4), transportation expenditure represented, on average in 1993, almost $10 \%$ of the overall budget, and thus constituted the third largest item in household budgets, though still far behind food (over $50 \%$ of total expenditure) and housing (over 20\%). This figure of $10 \%$, relatively low all things considered, is certainly due to the method of data collection in expenditure surveys, such as this one. Transportation expenditure is often underestimated because interviewees often forget to mention all their trips (Diaz Olvera et al., 2001). But this figure also reflects extremely low access to private cars and motorised two-wheel vehicles in Dar es Salaam.

However, an older assessment produced the figure of $16 \%$ of total revenues allocated to public transport in 1985 (Maunder, Fouracre, 1987) and this percentage would not seem to have decreased since. Given the combined effects of the deregulation of rates and the drop in the purchasing power of households, the price of a daily round trip in a daladalas has been calculated to have risen from $9 \%$ of the average daily wage in 1978 to $22 \%$ in 1998 (Tembele et al., 1998). In the HRDS, two thirds of transportation expenditure were devoted to public transport and only one household in thirty declared expenses for gasoline. These figures reflect the fact that owning a motor vehicle is hardly affordable for the large majority of Dar es Salaam inhabitants because of both high purchase and operating costs.

The differences are highlighted even more clearly when the transportation expenditure is analysed in terms of the type of ward or the quintile ${ }^{1}$ of households, determined by the total annual expenditure. Expenditure is low in unplanned wards, average in planned wards and rises sharply in the affluent ones, where the percentage of households owning a motor vehicle is higher (see Table 5). In these affluent wards, travel expenditure is four times higher than in the unplanned ones.

This difference between zones is even more striking when analysed in terms of the $20 \%$ of families with the lowest budget (first quintile) compared to the $20 \%$ of families with the highest budget (fifth quintile). In the first four quintiles (80\% of the households), public transport is dominant, whereas households in the fifth quintile have greater access to personal vehicles and spend 15 times as much as the average expenditure of the first quintile. However, it must be noted that the average expenditure of the richest households (fifth quintile) is twice as high as that of the fourth and almost six times as high as that of the first quintile.

\footnotetext{
${ }^{1}$ Quintile, one of the values of a statistical variable that divides the distribution of the variable into five groups having equal frequencies
} 
Table 5. Breakdown of annual family budget according to the type of ward.

\begin{tabular}{lllll}
\hline Annual expenditure & Unplanned & Planned & Affluent & All \\
\hline Breakdown (\%) & & & & \\
Food & 53.1 & 51.1 & 47.3 & 50.6 \\
Housing & 23.7 & 22.2 & 20.7 & 22.2 \\
Transportation & 6.3 & 8.0 & 13.3 & 9.1 \\
Clothing & 4.5 & 5.0 & 4.5 & 4.6 \\
Health & 2.7 & 2.7 & 1.9 & 2.4 \\
School (w/o transportation) & 0.7 & 1.0 & 1.4 & 1.0 \\
Free time, miscellaneous & 6.7 & 7.3 & 7.8 & 7.3 \\
Transfers & 2.4 & 2.7 & 3.2 & 2.8 \\
Total & 100.0 & 100.0 & 100.0 & 100.0 \\
\hline \multicolumn{1}{c}{ Source: HRDS in 1993} & & & &
\end{tabular}

The relatively low level of expenditure for public transportation on the part of the poorest households must of course be analysed in terms of the major constraints weighing on their daily budget, in which $80 \%$ of expenditures go toward food and housing. For the $40 \%$ of households with the lowest budget (first two quintiles), once the costs of food and housing have been deducted, the average household has only TSH 450 left per workday to cover all the other needs of the four household members (health, education, transportation, other purchases) and the $20 \%$ of households with the lowest income (first quintile) have only TSH 250. At the time of the survey, a round trip in a daladala cost at least TSH 140 for the most simple and straightforward destinations. It would seem clear that the use of public transport was reserved for only the most indispensable trips in an attempt to reduce this expenditure. Consequently, though individual transport is obviously the privilege of the most affluent households, public transport may definitely not be considered a means used only by the most poor. On the contrary, the average expenditure for public transport per adult is multiplied by a factor of seven from the first to the last quintile.

It must be noted, however, that households belonging to the $60 \%$ of families with the highest expenditure (third, fourth and fifth quintiles) spend more on public transport if they live in a planned ward and not in an unplanned one, probably due to the proximity of paved roads offering more transportation opportunities, but also because of the social composition of residential areas, as was shown by Banyikwa (1988). As mentioned before, employees in the public and semi-public sector are relatively numerous in the planned and the affluent wards, whereas there are many more unemployed persons and people working in the informal sector living in the unplanned wards. Public employment, fairly concentrated in the city, makes the use of a motorised means of transportation a necessity when the person does not live in the vicinity of the CBD. Civil servants and employees in the official private sector receive a bonus for their transportation costs. However it is far from sufficient to cover their real costs. Conversely, the people working in the informal sector are far more numerous among those working in their own neighbourhood or a place easily accessible on foot from their home. What is more, the random nature of their revenues means they are more often obliged to walk to their workplace even if it is located at considerable distance from their home (street sellers, hawkers and other menial sales or service jobs). 
A last indicator confirms the high impact of daily mobility on household budgets. The fare of daladalas increased from TSH 100 to 150 at the end of 1996 (with the exception of uniformed school children who pay TSH 50). However, since then, the small-scale operators have had continuous problems in enforcing the new rate. During off-peak periods and over the weekends, when it is more difficult to fill the buses, or for short trips, the price can drop back to TSH 100 . This real resistance to the new fare may be considered an indicator of the daily financial difficulties encountered by households. The major limitations weighing on revenues would lead to the conclusion that the rise in rates at the end of 1996 resulted in a significant decrease in the solvent demand for transportation.

\subsection{Limited daily mobility}

Even though recent and precise data are not available, the various sources of information on hand reveal limited daily mobility. For example, in the middle of the 1980s, Maunder and Fouracre (1987) estimated, on the basis of a survey on 126 households in six zones of the city, that the average mobility was 1.5 trips per person per day, all age groups included. More recently, a smaller survey carried out in 1993 in the Temeke area, though not representative of the entire city, produced relatively similar figures. Mobility was evaluated at 1.9 trips per day (De Langen, 1997a, 1997b), but this figure concerned only people 14 and older, who are more mobile than young children, specially for long-distance destinations outside the neighbourhood.

Both studies produce relatively close figures for the number of mechanised trips (motor vehicles or bicycles), whether on the overall level (approximately one mechanised trip per person on weekdays) or, more specifically, for trips using public transport ( 0.8 daily trips). Assessments made on the basis of data on expenditure for public transport, collected for the HRDS, show that the level of mobility using public transport is highly plausible.

On the other hand, the data produced divergent results concerning trips on foot, 0.9 trips for the Temeke study as compared to 0.4 trips in the 1987 study. However, the latter figure is probably underestimated and it would be unwise to conclude from this data that trips on foot have increased between the two dates, particularly given the high uncertainty of data on trips over short distances.

The above data, showing approximately one mechanised trip per person and per day, indicates the very low numbers of trips outside the zone of residence. Given that the same means of transportation is generally used both from the home and back, and that the minority of persons having a car has a very high level of mobility, thus increasing the overall average, it may be reasonably estimated that a major part of the inhabitants of Dar es Salaam does not use any form of motorised transportation during an ordinary week day. Though comparisons in this field are rather delicate due to differences in the survey methods, the available data shows that this low number of motorised trips is not unique in Africa. For example, the number of mechanised trips per person and per day was 1.2 in Bamako in 1993 and 1.4 in Niamey in 1996 (Diaz Olvera et al., 2000). However, what makes this low level particularly important in Dar es Salaam is the size of the city, much larger than these capital cities of West Africa. This factor makes trips on foot longer and more difficult when travelling from one neighbourhood to another (in 1987, the average distance of trips on foot was already estimated at $1.7 \mathrm{~km})$. 
It should be noted as well that these average mobility levels cover a very wide range of mobility behaviour. Everything points to the conclusion that, in a context of low revenues and given the cultural system in which women are largely excluded from the workforce in Tanzania (Omari, 1994; Rwebangira, 1996), the decisions concerning trips are not in the favour of women or of the other unemployed inhabitants. Though the crisis may have encouraged the access of women to employment (Messkoub, 1996), in general their jobs remain poorly paid (O'Riordan, 1996) and thus less likely to justify access to mechanised means of transportation.

\section{Unplanned settlements: a poverty trap?}

The poor unplanned settlements, difficult to access, represent an increasingly large percentage of urban Dar es Salaam as a whole, because they are supplied through natural population growth and a constant, high flow of migrant population. In a context where the economy is becoming increasingly dual and the gaps between social classes are widening, the major deficiencies in both urbanisation and the transportation system reinforce urban segregation. Existing transportation services and infrastructure succeed poorly in removing the many physical barriers and as a result, there are today numerous obstacles to the daily travel of the inhabitants of Dar es Salaam. These obstacles weigh heavily on schedules, complicate access to services ever further, limit the use of urban space and place major pressure on household budgets.

The absence of demands on the part of the users of the passenger transportation system may certainly be explained first of all by the fact that transportation appears, in the eyes of the inhabitants, as just another of the daily problems and probably not among the most pressing, in comparison with other priority needs such as housing, employment, access to water or how to pay the medical and school bills. Another factor is the long-standing habit of making do on a daily basis under difficult conditions. This situation is shown by the resignation of public-transport users during police raids that temporarily shut down a large number of illegal daladalas and force people to walk even greater distances. These deficiencies nonetheless weigh heavily on the operation of the entire city, well beyond the simple transportation aspects. The result is that the poor households must limit their trips outside the neighbourhood to the most indispensable activities.

This tendency to retreat into the area of residence is, of course, not specific to Dar es Salaam. It has been observed in the large peripheral zones of Bamako (Gibbal, 1988) and Niamey (Diaz Olvera et al., 2000), and can, in many cases, correspond to a major effort on the part of the rural immigrant residents to "put down roots" and to the desire to recreate a "village in the city", according to the term used by Gibbal. This tendency is not, however, without risks. On the one hand, these precarious "villages" and informal settlements are rapidly caught up in the problems caused by their increasingly high population densities (see Sliuzas, 2001, for data on densification in Dar es Salaam) which, in the end, reinforce the fragility of their living conditions. On the other, a retreat into the neighbourhood negates most solutions to alleviate poverty for the vast majority.

On the job market, transportation difficulties reduce even further the possibilities of finding a job. What is more, for trips to and from work, long travel 
times in public transport or the difficulty of travel on foot over large distances can reduce the productivity of workers, notably the poor.

In terms of living conditions, the availability and cost of public transport weigh heavily on the situation in essential fields such as health and education in that they tend to reduce access to these services. For example, concerning attendance in secondary schools, the limited number of schools means that it is often necessary to use public transport given the chronic shortage or the unsuitability (on the technical and cultural levels) of alternate means, such as bicycles. Above and beyond the difficulty of transportation, particularly for school children, who must argue with the "touts" of the daladalas to climb on board, the simple cost of trips, even given the reduced fare, increases the overall cost of schooling and may constitute one of the factors resulting in the premature exit from school for children in poor families.

Finally, in terms of urban citizenship in general, the retreat into the neighbourhood can encourage a more lively local social life. However, it is also an underlying factor for more traditional lifestyles (such as seclusion of women or travel of women restrained to the immediate vicinity of the home, limited education for children, self-consumption) that do not contribute to developing broader social contacts and an alleviation of poverty.

Again, these tendencies are not specific to Dar es Salaam, indeed, they are currently underway in most of the large African cities. But in the Tanzanian city, a number of factors have combined to increase the effects. Above size of the city and the beyond geographical specificities, the long-standing lack of interest in urban planning and in the organisation of urban passenger transport in particular, as well as, more recently, the insufficient financial standing of local and national government entities thwart the recent efforts of the local authorities to control urbanisation (Raison, 1994, Banyikwa, 1988). It may be said that the context of rapid deregulation since the middle of the 1980s has resulted in a quantitative increase in the supply of informal transportation. It also produced, in the areas of residence, the emergence of micro-projects and local initiatives (for example, the repair of streets, largely financed by the inhabitants themselves), in the framework of a new type of entity, the "Community Based Organisation".

However, the economic deregulation and the disengagement of the local authorities also produced a significant increase in the social and spatial inequality within the city. Similar to the daladalas which, given the absence of a minimal regulatory framework for their activity, concentrate their routes on the main radial roads, the local initiatives to improve accessibility within the neighbourhoods depend too heavily on funding by the users themselves to be of any use in the poorest areas. To ensure a minimum degree of equity throughout the city as a whole, the public authorities must reassume a role in improving access throughout the city (specially for workers, school children and students), as well as the availability of basic local services, particularly for women, two interdependent aspects of public policy to alleviate poverty.

\section{References}

Amer, S., 2000. Planning public health care facilities in Dar es Salam, Tanzania: users, interaction patterns and under-serviced areas. In: Howe, J., Bryceson, D., (Eds). Poverty and Urban Transport in East Africa: Review of Research and Dutch Donor Experience. Report prepared for the World Bank, IHE, Delft, pp. 117-123.

Banyikwa, W.F., 1988. Urban Passenger Transport Problems in Dar es Salaam, Tanzania. African Urban Quarterly, 3 (1-2), 80-93. 
Berhie, G. K., 1998. Gis based spatial analysis of urban public transport accessibility: the case of Dar es Salaam (Tanzania). Msc. Thesis, ITC, Division of Urban Planning and Management., Eschen (The Netherlands).

Briggs, J., Mwafumpe, D. 2000. Peri-urban Development in an Era of Structural Adjustement in Africa: The City of Dar es Salaam, Tanzania. Urban Studies, 37 (4), 797-809.

De Langen, M., 1994. Synthesis of the results of the study on Transport in Kenya and Tanzania. In: Worksop on Urban mobility and non motorised transport in subsaharan Africa: Phase 1, French ministry of Cooperation, Ministry of foreign affairs of the Netherlands, World Bank, 11-13 october, Nairobi, 14 p.

De Langen, M., 1997a. Communication on Progress and Findings. Non Motorised Transport Project, SSATP, Orientation Committee, The World Bank, 15-16 october, Abidjan, 16 p.

De Langen, M., 1997b. Urban Mobility and Economic Realities in Sub-Saharan Africa, Working Paper T \& RE $\left.\mathrm{n}^{\circ} 17\right)$. International Institute for Infrastructural, Hydraulic and Environmental Engineering, Delft.

Diaz Olvera, L., Plat, D., Pochet P., 1999. Mobilité quotidienne des citadins à faibles ressources. Les enseignements de Ouagadougou. Revue Tiers-Monde, XL (160), 829-848.

Diaz Olvera, L., Plat, D.,Pochet, P., 2000. Pauvreté et espaces quotidiens à Niamey. L'Espace Géographique, 4, 329-340.

Diaz Olvera, L., Plat, D., Pochet P., 2001. Dépenses de transport des ménages en Afrique subsaharienne. Méthodes et mesures appliquées au cas de Niamey. Recherche Transport Sécurité, 72, 19-33 (shortened version in English: 34-36).

Eriksen, S.S., 1997. Between a Rock and a Hard Place? Development Planning in Tanzanian Local Governments. Third World Planning Review (19) 3, 251-269.

Ferreira, M.L., Griffin, C.C., 1996. Tanzania Human Resource Development Survey: final report, vol. I. The World Bank, Washington DC. http://www.worldbank.org/html/prdph/lsms/country/tza/data/core pdf.zip.

Gibbal, J.-M., 1988. Fadjiguila, village dans la ville. Cahiers des Sciences Humaines, (24), 2, 317 326.

Howe, J., Bryceson, D., 2000. Poverty and Urban Transport in East Africa: Review of Research and Dutch Donor Experience. Report prepared for the World Bank, IHE, Delft.

Kombe, J.W.M., 1994. The Demise of Public Urban Land Management and the Emergence of Informal Land Markets in Tanzania. Habitat International, 18 (1), 23-43.

Lugalla, J., 1997. Economic Reforms and Health Conditions of the Urban Poor in Tanzania. African Studies Quarterly 1 (2), 17 p.

Maunder, D.A.C., Fouracre, P.R., 1987. Public Transport Provision in Dar es Salaam, Tanzania. Working paper $\mathrm{n}^{\circ} 231$, Transport and Road Research Laboratory (Overseas Unit), Crowthorne.

Messkoub, M., 1996. The Social Impact of Adjustement in Tanzania in the 1980s: Economic Crisis and Household Survival Strategies, Internet Journal of African Studies, 1, 20 p.

Munishi, G.K., 1995. Social Services Provision in Tanzania: The Relationship between Political Development Strategies and NGO Participation", in Semboja J., Therkildsen O. (Eds.), Service Provision under Stress in East Africa. The State, NGOs \& People's Organizations in Kenya, Tanzania \& Uganda. Centre for Development Research, Copenhagen, pp. 141-152.

Omari, C.K., 1994. Social and Cultural Factors Influencing Poverty in Tanzania. Special Papers $\mathrm{n}^{\circ} 8$, REPOA, University of Dar es Salaam.

O'Riordan, J., 1996. The Informal Sector and the Alleviation of Poverty from a Gender Perspective. In: ESAURP (Ed.), Tanzania's Tomorrow. Tema Publishers, Dar es Salaam, pp. 65-72.

Plat, D., Pochet, P., 2002. D comme Dar es Salaam ou les dangers du désengagement public. In: Godard X. (Ed.), Transports et vie urbaine en Afrique. Karthala, Paris, pp. 73-82.

Razafindrakoto, M., Roubaud, F., 2001. Pauvreté et récession dans les métropoles africaines et malgaches : éléments de diagnostic. Working paper $\mathrm{n}^{\circ}$ 2001/10, DIAL, Paris.

Raison, J.P., 1994. Tanzanie : l'ujamaa et ses lendemains. In : Dubresson, A., Marchal, J.Y., Raison J.-P. (Eds), Les Afriques au sud du Sahara. Belin-Reclus, Montpellier, pp. 343-355.

Rwebangira, M. K., 1996. The Legal Status of Women and Poverty in Tanzania. Research Report $\mathrm{n}^{\circ} 100$, Nordiska Afrikaninstitutet, Uppsala.

Sawaka, M., 1996. Buses Routes and Terminals. Report on the Dar es Salaam survey made by the working group to promote public transport (Managing the Sustainable Growth and Development of Dar es Salaam Project). National Institute of Transport, Dar es Salaam, HABITAT.

Sliuzas, R. , 2001. The role of knowledge and opinions in understanding dynamics of informal 
housing in Dar es Salaam. Aerus Workshop: Coping with informality and illegality in human settlements in developing cities. Leuven and Bussels, 23-26 may, 15 p.

http://www.m20m.com/workshop2001/papers/sliuzas.html

Tembele, R., Mosi, J.E.J., De Langen, M., 1998. De-Bottlenecking Developing Cities: the Problem of Road Network Governance. In: Freeman, P., Jamet, C. (Eds.), Urban Transport Policy, a Sustainable Develoment Tool, Proceedings of CODATU VIII, Balkema, Rotterdam, pp. 911916.

Transurb Consult, Inrets, 1991. Politique de transport urbain en Afrique Subsaharienne. Etude comparative de 12 villes. Rapport de synthèse. UITP et Banque Mondiale (SSATP Transport Urbains), 5-8 mars, Yaoundé (Cameroun), UITP-Banque Mondiale.

Vasconcellos, E. A., 2001. Urban Transport, Environment and Equity. The case for developing countries. Earthscan, London.

Werlin, H., 1999. The Slum Upgrading Myth. Urban Studies 36 (9), 1523-1534.

Zambrano Gil, E. A., 1994. Utilization of Public Health Care Facilities in Dar es Salaam, Tanzania, Thesis for the Degree of MSc in Geographic Information Systems for Urban Application. International Institute for Aerospace Survey and Earth Science, Eschen (The Netherlands). 